\title{
Onkoloji hastalarının tamamlayıcı ve alternatif tedavi yöntemlerini kullanma durumları
}

\author{
The status of oncology patients about using complementary and alternative treatment \\ methods
}

Metin Deniz Karakoç

Gönderilme tarihi:31.10.2019

Kabul tarihi:04.12.2019

\section{Özet}

Amaç: Çalışma, kanser hastalarının tamamlayıcı ve alternatif tedavi yöntemleri (TAT) kullanma durumlarının saptanması ve olası risklere ışık tutulması amacıyla gerçekleştirilmiştir.

Gereç ve yöntem: Araştırmaya katılmayı kabul eden 260 gönüllü hastaya 20 soruluk bir anket, yüz yüze görüşme yoluyla uygulandı. Verilerin değerlendirilmesinde tanımlayıcı istatistikler ve ki-kare $\left(\mathrm{X}^{2}\right)$ testi kullanıldı. Bulgular: Şehir merkezlerinde yaşayan hastalarda TAT kullanımının kırsal bölgelerde yaşayanlara göre önemli ölçüde fazla olduğu $(p=0,01)$ saptandı. Araştırmada hastaların \%31,5'inin medikal tedavi sürecinde TAT yöntemlerine başvurduğu belirlendi. Bu hastaların \%95,1'inin bitkisel ürünler, \%3,7'sinin biyorezonans ve \%1,2'sinin homeopati yöntemlerini kullandığı saptandı. Araştırmada TAT yöntemi kullanan katılımcıların \%14,8'inin iki ayrı TAT yöntemini birden kullandığı tespit edildi. TAT yöntemlerinden bitkisel ürünleri tercih eden hastaların toplam 17 farklı bitki kullandığı saptandı. Araştırmada çörek otunun (Nigella sativa L.) hastalarca en fazla tercih edilen bitkisel ürün olduğu belirlendi. Prostat kanserli hastaların diğer hastalara göre TAT yöntemlerine daha fazla başvurduğu saptandı $(p<0,05)$. Katılımcıların tanı konulması üzerinden zaman geçtikçe TAT yöntemlerini kullanımlarının anlamlı derecede artı̆̆ı saptandı $(p<0,01)$. Katılımcılar içerisinde kanser haricindeki komorbiditeler için ilaç kullananların oranının \%36,9 olduğu belirlendi. Bu hastalarda ilginç olarak kanser dışında başka bir rahatsızlığı bulunmayanlara göre TAT kullanımının anlamlı derecede daha yüksek olduğu saptandı $(p<0,01)$.

Sonuç: Çalışmada, hastaların çeşitli TAT yöntemlerini çok sık ve bilinçsizce kullandığı belirlendi. Hastaların, bu yöntemlerin sağlıklarına olan potansiyel zararları hakkında daha ayrıntılı olarak bilgilendirilmeleri gerekmektedir.

Anahtar kelimeler: Tamamlayıcı ve alternatif tedavi, ilaç etkileşimleri, kanser, onkoloji .

Karakoç MD. Onkoloji hastalarının tamamlayıcı ve alternatif tedavi yöntemlerini kullanma durumları. Pam Tıp Derg 2020;13:69-80.

\begin{abstract}
Purpose: The aim of the study was to determine the use of complementary and alternative treatment methods (CAM) of cancer patients and to shed light on possible risks.

Materials and methods: A questionnaire with 20 questions was administered through face-to-face interviews to 260 volunteer patients who agreed to participate the study. Descriptive statistics and chi-square test $\left(X^{2}\right)$ were used to evaluate the data.

Results: The use of CAM was significantly higher in patients living in urban compared to rural areas $(p=0,01)$. It was determined $31.5 \%$ of the patients use the CAM methods during the medical treatment. It was found $95.1 \%$ of these patients used herbal products, $3.7 \%$ used bioresonance and $1.2 \%$ used homeopathy. It was found $14.8 \%$ of the participants using CAM methods used two different CAM methods concurrently. It was found the patients who preferred herbal products were used 17 different plants. In the study, it was determined love-in-amist (Nigella sativa L.) was the most preferred herbal product by patients. It was determined patients diagnosed with prostate cancer were more likely to use CAM methods than other patients $(p<0,05)$. It was found the use of CAM methods increased significantly as the time passes after diagnosis $(p<0,01)$. It was determined $36.9 \%$ of the participants have to use drugs for non-cancer comorbidities. Interestingly, the use of CAM was significantly higher in these patients compared to participants without any other non-cancer comorbidities $(p<0,01)$.

Conclusion: In the study, it was determined the patients used various CAM methods very often and ignorantly. Patients should be informed more detailed about the potential harm to their health of these methods.
\end{abstract}

Key words: Complementary and alternative treatment, drug interactions, cancer, oncology.

Karakoç MD. The status of oncology patients about using complementary and alternative treatment methods. Pam Med J 2020;13:69-80. 


\section{Giriş}

Son yıllarda kanser tedavisinde birçok ilerleme kaydedilmiş olmasına rağmen, hastalığı yenme oranının düşük olması, verilen tıbbi tedavinin iyileşmeye yetmeyeceği endişesi veya yan etkilere bağlı şikayetleri azaltmak gibi çeşitli nedenlerle hastaların modern tıp yöntemleri dışında başka tedavi yöntemlerine de sıklıkla başvurduğu bilinmektedir [1, 2]. Genel adı ile tamamlayıcı ve alternatif tedavi yöntemleri (TAT) olarak adlandırılan bu yöntemlerden tamamlayıcı tedavi; yaşam kalitesini artırmak, hastanın şikayetlerini ve ilaçlara bağı yan etkileri azaltmak maksadı ile uygulanan tedavileri kapsar. Alternatif tedavi ise modern tıbbi uygulamalar yerine yapılan, etkinliği bilimsel olarak henüz kanıtlanmamış tedavilerdir [3]. Geleneksel Çin Tıbbı, dini ritüeller, meditasyon, bitkiler, gıda takviyeleri, aromaterapi, masaj, homeopati, akapunktur ve biyorezonans gibi pek çok uygulama TAT sınıfına girmektedir [4]. Yapılan araştırmalarda hastaların kanseri yenmek, yan etkilerle mücadele etmek, immün sistemi güçlendirmek, fiziksel ve manevi rahatlık sağlama, son bir "umut" veya tedavi için "her yolu" denediğinden emin olmak gibi çeşitli amaçlarla, genellikle zararsız yöntemler olarak düşündükleri TAT yöntemlerine yöneldikleri bildirilmiştir $[1,5,6]$.

Kanser hastaları arasında Avrupa ülkelerini kapsayan bir çalışmada, TAT kullanım oranlarının \%14,8 ile \%73,1 arasında değiştiği, ortalamanın ise \%35,9 olduğu bildirilmiştir [7]. Yurdumuzda yapılan bir literatür taramasında ise TAT kullanım oranının \%22 ile \%84 arasında değiştiği, ortalamanın ise \%46,2 olduğu bildirilmiştir [8]. Avrupa ve ABD'de en sık başvurulan TAT yöntemleri bitkisel ürünler, homeopati, vitamin ve mineraller, dini terapiler ve gevşeme (relaksasyon) metodlarıdır [5, 7]. Ülkemizde yapılan çalışmalarda ise bitkisel ürünler ve dini yaklaşımların en yaygın uygulamalar olduğu görülmektedir $[9,10]$.

Günümüzde modern tıpta kullanılan pek çok ilaç, bitkisel kökenli hammaddelerin doğal veya sentetik türevleridirler. Ancak bu bitkisel ürünlerin ilaç olarak adlandırılabilmesi için doz, etkinlik, yapı, saflık gibi birçok kriter bakımından standardize edilmeleri gerekmektedir. Cinsiyet, ırk, kullanılan diğer ilaçlarla etkileşimler, organ yetmezlikleri ve malignitenin türü başta olmak üzere pek çok faktörün uygulanan
TAT yönteminin etkinliğini değiştirmesi mümkündür. Diğer taraftan en sık kullanılan TAT yöntemlerinden biri olan bitkisel ürünlerde hasat zamanı, hasat yöntemi, kurutma metodu, bitkinin hangi parçası olduğu (kök, kabuk, vb.), saklama (depolama) şekli, üzerindeki zirai ilaç kalıntıları, ağır metaller, mantarlar ve toksinler (aflatoksin, okratoksin, vb.) bitkisel ürünlerin etkinliğini ve kullanım güvenliğini etkileyen önemli faktörlerdir [11]. Bitkisel menşeili ürünlerin farmakolojik etkileri bir yana; standardize edilmemiş, hangi koşullarda yetiştirildiği, hasat edildiği ve depolandığından emin olunamayan bu ürünlerdeki yukarıda sayılan biyolojik ve kimyasal kirleticilerin varlığı da, hasta sağlığı açısından ayrı bir risk teşkil etmektedir.

Kanser dışındaki diğer kronik rahatsızlıklar (hipertansiyon, diyabet, vb.) için ilaç kullanmak zorunda olan hastalarda antineoplastik ilaçlarla diğer ilaçlar arasında olası etkileşmeler sonucunda terapötik etkide azalma veya toksik etkilerde artışla karşılaşılması mümkündür $[12,13]$. Bu tür hastalarda dozaj ve toksisite açısından belli bir standarda sahip olmayan TAT yöntemlerinin kullanılması hayatı tehdit edici sonuçlar doğurabilir. Onkoloji hastaları arasında TAT kullanım yöntemleri, sıklığı ve diğer kronik rahatsızlıklar için kullanılan ilaçların irdelenmesi; gerek hasta sağlığı gerekse akılcı ilaç uygulamaları açısından önem arz etmektedir. Çalışmamız, kanser hastalarının kullandıkları TAT yöntemlerinin, kullanım sıklıklarının ve bunlara neden olan faktörlerin saptanması; ayrıca TAT kullanan hastalardaki potansiyel ilaç etkileşimleri riskine ışık tutulması amacıyla gerçekleştirilmiştir.

\section{Gereç ve yöntem}

Araştırmamız, tanımlayıcı türde kesitsel bir çalışmadır. Çalışmaya, Pamukkale Üniversitesi Girişimsel Olmayan Klinik Araştırmalar Etik Kurulundan (Etik kurul izin no: E.13570) ve Denizli İ Sağlık Müdürlüğünden alınan yazılı izinlerin ardından başlandı. Tüm araştırma süresince Helsinki Bildirgesi ilkelerine uyuldu. Araştırma 06.08-06.09.2019 tarihleri arasında Denizli ilinde bulunan bir kamu hastanesinde gerçekleştirildi. Çalışmanın evrenini, 18 yaşını doldurmuş, kanser tanısı konulmuş, hastanenin onkoloji merkezinde günübirlik veya yatarak kemoterapi tedavisi görmekte olan hastalar ile kemoterapi sürecini daha önce tamamlamış ancak rutin kontroller amacıyla medikal onkoloji 
polikliniğine başvuran hastalar oluşturmaktadır. Çalışmada örneklem seçilmemiş olup tüm hastalara $(n=324) \quad$ çalışma hakkında bilgi verilerek ankete katılıp katılmayacakları soruldu; gönüllülük esasına göre araştırmaya katılmayı kabul eden hastaların yazılı onamları alınarak anket uygulandı ve sonuç olarak 260 adet $(\% 80,2)$ kullanılabilir anket elde edildi.

Araştırmanın verileri, "Alternatif/Tamamlayıcı TıpYaklaşımlarıAnketFormu” adlıdeğerlendirme anketi uygulanarak toplandı. Ankette; katılımcıların sosyodemografik özellikleri (yaş, cinsiyet, eğitim durumu, meslek, yaşadığı yer, medeni durumu, ailede kanser öyküsü) için yedi soru bulunmaktadır. Hastalıklarının türü, tanı konulmasının üzerinden geçen zaman ve diğer hastalıklar için kullanılan ilaçlar konusunda üç soru; TAT konusundaki bilgi, tutum ve davranışları belirlemeye yönelik olarak on soru olmak üzere toplam 20 soru bulunmaktadır. TAT yöntemleri kullandığını beyan eden hastaların tanı ve tedavisi ile ilgili bilgilerin kontrolü için ise hasta tedavi dosyalarından yararlanılmıştır.

Verilerin bilgisayar ortamına girilmesi ve değerlendirilmesi Statistical Package for the Social Sciences 22.0 (SPSS 22.0) paket programı kullanılarak gerçekleştirildi. Değişkenler arasındaki ilişkiyi araştırmak için tanımlayıcı istatistikler ve ki-kare $\left(X^{2}\right)$ testi kullanıldı. $P<0,05$ istatistiksel olarak anlamlı kabul edildi.

\section{Bulgular}

Araştırmaya katılan hastaların yaş ortalamalarının 60,22 $\pm 9,64$ (minimum:21; maksimum:82) olduğu saptandı. Hastaların \%30'un da $(n=78)$ aile de daha önce kanser öyküsü bulunduğu belirlendi. Katılımcıların yaş, cinsiyet, ailede kanser öyküsü ve medeni durum gibi çeşitli sosyodemografik özellikleri ile TAT kullanımları arasında anlamlı bir fark bulunmadığı görüldü $(p>0,05)$. Diğer taraftan şehir merkezlerinde yaşayan hastalarda TAT kullanım oranının köyler ve kasabalarda yaşayanlara göre önemli derecede fazla olduğu $\left(x^{2}=13,229, \quad p=0,01\right)$ belirlendi. Katılımcıların meslekleri ile TAT kullanma durumları arasındaki ilişki incelendiğinde çiftçiler arasında TAT kullanımının diğer mesleklere göre önemli ölçüde düşük olduğu $\left(x^{2}=9,347, \quad p<0,01\right)$ belirlendi. Lisansüstü eğitim almış katılımcıların TAT yöntemlerini hiç kullanılmadıkları görüldü.
Bu sonuç diğer eğitim seviyelerine sahip katılımcılarla karşılaştırıldığında arada anlamlı fark olduğu $\left(X^{2}=5,291, p<0,05\right)$ saptandı. Katılımcıların sosyodemografik özelliklere göre dağılımları ile TAT kullanımlarına ilişkin detaylar Tablo 1'de sunulmuştur.

Araştırmada katılımcıların \%31,5'inin ( $n=82$ ) kemoterapi sürecinde TAT yöntemlerine başvurduğu belirlendi. Bu hastaların \%95,1'inin $(n=78)$ bitkisel/hayvansal ürünler, \%3,7'sinin $(n=3)$ biyorezonans ve \%1,2'sinin $(n=1)$ homeopati yöntemlerini kullandığı saptandı. Araştırmada TAT yöntemi olarak bitkisel/ hayvansal ürünler kullanan katılımcıların \%15,4'ünün (n=12) iki ayrı TAT yöntemini birden kullandığı görüldü. Çift TAT yöntemi kullanan hastaların bitkisel/hayvansal ürünlerle birlikte zem zem suyu içmek, kurşun döktürmek, hoca ve türbe ziyaretlerinde bulunmak gibi dini ve kültürel ritüellere de yöneldikleri belirlendi. Katılımcıların kullandıkları TAT yöntemleri ve dağılımları Tablo 2'de; kullanım nedenleri, kullanım aralıkları, şikayetlerinde değişiklik olup olmadığı ve bu yönteme kimin tavsiyesi ile başladıklarına ait bilgiler Tablo 3'te sunulmuştur.

Prostat kanserli katılımcıların diğer hastalara göre belirgin derecede daha fazla TAT yöntemlerine başvurduğu saptandı $\left(x^{2}=5,301\right.$, $p<0,05)$. Araştırmaya katılan diğer hastaların kanser tanıları ile TAT kullanımı arasında anlamlı bir ilişki bulunmadığı belirlendi $(p>0,05)$. Katılımcıların tanı konulması üzerindeki zaman ilerledikçe TAT yöntemlerini kullanma oranlarının arttığı saptandı $\left(X^{2}=15,715\right.$, $p<0,01)$. Katılımcıların kanser tanıları ve tanı konulmasının üzerinden geçen süre ile TAT kullanım oranı ilişkisi Tablo 4'te sunulmuştur.

Katılımcılar içerisinde kanser dışındaki diğer eşlik eden kronik hastalıkları (komorbiditeleri) için sürekli ilaç kullanan 96 hasta $(\% 36,90)$ olduğu belirlendi. Bu hastaların 60'ının bir, 24'ünün iki ve 12'sinin ise üç ayrı komorbidite nedeniyle toplam 37 farklı ilaç kullanmakta olduğu saptandı. Araştırmada 36 hastanın bir, 42 hastanın iki, 11 hastanın üç, 4 hastanın dört, 2 hastanın beş, 1 hastanın ise altı farklı etken maddeli ilacı birlikte kullandığı belirlendi. $\mathrm{Bu}$ hastalarda şaşırtıcı olarak kanser dışında başka bir rahatsızlığı bulunmayanlara göre TAT yöntemi kullanımının da önemli ölçüde yüksek olduğu saptandı $\left(X^{2}=12,381, p<0,01\right)$. Kanser haricinde en fazla eşlik eden hastalıkların 
Tablo 1. Katıımcıların sosyodemografik özellikleri ve TAT kullanım oranları.

\begin{tabular}{|c|c|c|c|c|c|c|}
\hline \multirow{2}{*}{ Sosyodemografik Karakteristikler } & \multicolumn{2}{|c|}{ Toplam } & \multicolumn{2}{|c|}{ TAT Kullanımı var } & \multicolumn{2}{|c|}{ TAT Kullanımı yok } \\
\hline & $\mathbf{n}$ & $\%$ & $\mathbf{n}$ & $\%$ & $\mathbf{n}$ & $\%$ \\
\hline \multicolumn{7}{|l|}{ Cinsiyet } \\
\hline Kadın & 160 & 61,5 & 51 & 31,9 & 109 & 68,1 \\
\hline Erkek & 100 & 38,5 & 31 & 31,0 & 69 & 69,0 \\
\hline \multicolumn{7}{|l|}{ Medeni Durum } \\
\hline Evli & 208 & 80 & 63 & 30,3 & 145 & 69,7 \\
\hline Bekar & 39 & 15 & 15 & 38,5 & 24 & 61,5 \\
\hline Dul & 13 & 5 & 4 & 30,8 & 9 & 69,2 \\
\hline \multicolumn{7}{|l|}{ Meslek } \\
\hline Ev Hanımı & 104 & 40,0 & 29 & 27,9 & 75 & 82,1 \\
\hline Emekli & 44 & 16,9 & 16 & 36,4 & 28 & 63,6 \\
\hline İşçi & 39 & 15,0 & 12 & 30,8 & 27 & 69,2 \\
\hline Çiftçi & 34 & 13,1 & 3 & 8,8 & 31 & 91,2 \\
\hline Esnaf/Serbest Meslek & 20 & 7,7 & 9 & 45,0 & 11 & 55,0 \\
\hline Memur & 19 & 7,3 & 13 & 68,4 & 6 & 31,6 \\
\hline \multicolumn{7}{|l|}{ Eğitim Seviyesi } \\
\hline Okuma-Yazma Bilmiyor & 15 & 5,8 & 5 & 33,3 & 10 & 66,7 \\
\hline Okur-Yazar & 30 & 11,5 & 17 & 56,7 & 13 & 43,3 \\
\hline İlköğretim & 134 & 51,5 & 27 & 20,1 & 107 & 79,9 \\
\hline Lise & 45 & 17,3 & 17 & 37,8 & 28 & 62,2 \\
\hline Üniversite & 25 & 9,6 & 16 & 64,0 & 9 & 36,0 \\
\hline Lisansüstü & 11 & 4,2 & 0 & 0.0 & 11 & 100.0 \\
\hline Toplam & 260 & 100 & 82 & 31,5 & 178 & 68,5 \\
\hline
\end{tabular}

Tablo 2. Katıımcıların TAT kullanım durumları.

\begin{tabular}{|c|c|c|c|c|}
\hline \multirow{2}{*}{ TAT yöntemi } & \multicolumn{2}{|c|}{ Kullanan } & \multicolumn{2}{|c|}{ Kullanmayan } \\
\hline & $\mathbf{n}$ & $\%$ & $\mathbf{n}$ & $\%$ \\
\hline Bitkisel/hayvansal ürünler & 78 & 30,0 & 182 & 70 \\
\hline Biyorezonans & 3 & 1,1 & 257 & 98,9 \\
\hline Homeopati & 1 & 0,4 & 259 & 99,6 \\
\hline Dini ve kültürel ritüeller* & 12 & 4,6 & 248 & 95,4 \\
\hline Toplam & 82 & 31,5 & 178 & 68,5 \\
\hline
\end{tabular}

* Dini ve kültürel ritüellere yönelen katılımcıların tümü aynı zamanda bitkisel ve hayvansal ürünler de kullanmaktadır. 
Tablo 3. Katılımcıların TAT yöntemi kullanım özellikleri.

\begin{tabular}{|c|c|c|}
\hline Kullanım nedeni & $\mathbf{n}$ & $\%$ \\
\hline Tümörü yok etmeka & 37 & 45,1 \\
\hline Kemoterapinin yan etkilerini azaltmak ${ }^{b}$ & 6 & 7,3 \\
\hline Her ikisi için $(a+b)$ & 39 & 47,6 \\
\hline \multicolumn{3}{|l|}{ Kullanım aralığı } \\
\hline Hergün düzenli olarak & 40 & 48,8 \\
\hline Kemoterapi almadığım hergün & 20 & 24,4 \\
\hline Yalnız kemoterapiyi izleyen günlerde & 11 & 13,4 \\
\hline Yalnız şikayetlerimin arttığı günlerde & 6 & 7,3 \\
\hline Yalnız kemoterapi aldığım günlerde & 5 & 6,1 \\
\hline \multicolumn{3}{|c|}{ Kullanım sonucunda şikayetlerinizde değişiklik oldu mu? } \\
\hline Az da olsa iyi geldi & 33 & 40,2 \\
\hline Şikayetlerim önemli derecede azaldı & 28 & 34,1 \\
\hline Hiçbir faydası olmadı & 13 & 15,9 \\
\hline Şikayetlerimi tamamen bitirdi & 4 & 4,9 \\
\hline Sağlığıma zarar verdi & 4 & 4,9 \\
\hline \multicolumn{3}{|c|}{ Kullandığınız TAT yöntemine kimin tavsiyesi ile başladınız? } \\
\hline Tanıdık/komşu/akraba & 35 & 42,7 \\
\hline İnternet & 13 & 15,9 \\
\hline Medya & 11 & 13,4 \\
\hline Hekim & 10 & 12,2 \\
\hline Eczacı & 8 & 9,8 \\
\hline Aktar & 3 & 3,6 \\
\hline Hemşire & 2 & 2,4 \\
\hline Toplam & 82 & 100 \\
\hline
\end{tabular}


Tablo 4. Katılımcıların kanser türleri ve tanı konulmasının üzerinden geçen süre ile TAT kullanım oranları ilişkisi.

\begin{tabular}{|c|c|c|c|c|c|c|}
\hline & \multicolumn{2}{|c|}{ Toplam } & \multicolumn{2}{|c|}{ TAT Kullanımı var } & \multicolumn{2}{|c|}{ TAT Kullanımı yok } \\
\hline & $\mathbf{n}$ & $\%$ & $\mathbf{n}$ & $\%$ & $\mathbf{n}$ & $\%$ \\
\hline \multicolumn{7}{|l|}{ Kanser Türü } \\
\hline Meme & 107 & 41,2 & 33 & 30,8 & 74 & 69,2 \\
\hline Akciğer & 53 & 20,4 & 13 & 24,5 & 40 & 75,5 \\
\hline Kolo-rektal & 29 & 11,2 & 10 & 34,5 & 19 & 65,5 \\
\hline Over & 14 & 5,4 & 6 & 42,9 & 8 & 57,1 \\
\hline Mide & 10 & 3,8 & 5 & 50,0 & 5 & 50,0 \\
\hline Prostat & 7 & 2,7 & 5 & 71,4 & 2 & 28,6 \\
\hline Testis & 6 & 2,3 & 0 & 0,0 & 6 & 100,0 \\
\hline Mesane & 6 & 2,3 & 2 & 33,3 & 4 & 66,7 \\
\hline Karaciğer & 6 & 2,3 & 2 & 33,3 & 4 & 66,7 \\
\hline Pankreas & 4 & 1,5 & 0 & 0,0 & 4 & 100,0 \\
\hline Miyelom & 4 & 1,5 & 2 & 50,0 & 2 & 50,0 \\
\hline Baş-boyun & 4 & 1,5 & 1 & 25,0 & 3 & 75,0 \\
\hline Sarkom & 3 & 1,2 & 0 & 0,0 & 3 & 100,0 \\
\hline Beyin & 3 & 1,2 & 2 & 66,7 & 1 & 33,3 \\
\hline Malign melanom & 2 & ,8 & 0 & 0,0 & 2 & 100,0 \\
\hline Endometriyum & 2 & ,8 & 0 & 0,0 & 2 & 100,0 \\
\hline \multicolumn{7}{|c|}{ Tanı konulmasının üzerinden geçen zaman } \\
\hline $0-6$ ay & 87 & 33,5 & 14 & 16,1 & 73 & 83,9 \\
\hline 6 ay-1 yıl & 71 & 27,3 & 25 & 35,2 & 46 & 64,8 \\
\hline $1-3$ yıl & 49 & 18,8 & 22 & 44,9 & 27 & 55,1 \\
\hline 3-5 yıl & 28 & 10,8 & 11 & 39,3 & 17 & 60,7 \\
\hline $5+y ı l$ & 25 & 9,6 & 10 & 40,0 & 15 & 60,0 \\
\hline Toplam & 260 & 100 & 82 & $31,5^{*}$ & 178 & $68,5^{*}$ \\
\hline
\end{tabular}

* Yüzdeler genel toplamlara göre verilmiştir.

sırasıyla kardiyovasküler hastalıklar, diyabet ve psikiyatrik-nörolojik hastalıklar olduğu belirlendi. Antidepresan ilaç grubunda sertralin, kardiyovasküler ilaç grubunda amlodipin ve antidiyabetik ilaç grubunda metformin etken maddeli ilaçların en fazla kullanılan ilaçlar olduğu görüldü. Kanser haricinde diğer başka kronik hastalıkları da olan katılımcıların dağılımı ve TAT kullanım oranları Tablo 5'te sunulmuştur.

TAT yöntemlerinden bitkisel ve hayvansal ürünleri tercih eden hastaların $(n=78)$ toplam 17 farklı ürün kullandığı saptandı. 34 hastanın tek, 21 hastanın çift, 13 hastanın üç, 10 hastanın ise dört bitkisel/hayvansal ürünü birlikte kullandığı belirlendi. Araştırmada çörek otunun hastalarca en fazla tüketilen bitkisel ürün olduğu belirlendi. TAT yöntemi olarak bitkisel/hayvansal ürünler kullanan katılımcıların tercih ettiği ürünler ve dağılımları Tablo 6'da sunulmuştur.

TAT yöntemleri kullanımı ile ilgili olarak kemoterapi tedavilerini yürüten medikal onkoloji uzmanının kendilerini bilgilendirip bilgilendirmediği konusunda katılımcıların \%43,5’i ( $n=113)$ doktorun kendilerini bu tür yöntemler kullanmamaları gerektiği konusunda uyardığını belirtti. Hastaların \%47,7'si ( $n=124)$ hekimin bu konuda kendileri ile hiç konuşmadığını ve kendilerinin de herhangi bir soru sormadıklarını bildirdi. Katılımcıların \%8,8'i $(n=23)$ ise hekimleri ile konuştuktan sonra TAT yöntemi kullanımını bıraktıklarını belirtti. TAT yöntemi kullanan katılımcıların \%39,0'ı $(n=32)$ bu ürünlerin potansiyel yan etkileri ve ilaç etkileşimleri konusunda bilgisi olduğunu, 
Tablo 5. Katılımcıların kanser dışında eşlik eden diğer hastalıkları ve TAT kullanım oranları.

\begin{tabular}{lcccccc}
\hline \multirow{2}{*}{ Hastalık } & \multicolumn{2}{c}{ Toplam } & \multicolumn{2}{c}{ TAT Kullanımı var } & \multicolumn{2}{c}{ TAT Kullanımı yok } \\
& $\mathbf{n}$ & $\mathbf{\%}$ & $\mathbf{n}$ & $\mathbf{\%}$ & $\mathbf{n}$ & $\mathbf{\%}$ \\
\hline Kardiyovasküler & 61 & 23,4 & 17 & 27,9 & 44 & 72,1 \\
Diyabet & 41 & 15,8 & 10 & 24,4 & 31 & 75,6 \\
Psikiyatrik-nörolojik & 22 & 8,5 & 14 & 63,6 & 8 & 37,3 \\
Diğer & 20 & 7,7 & 2 & 10,0 & 18 & 90,0 \\
Toplam & $\mathbf{9 6 *}$ & $\mathbf{3 6 , 9}$ & $\mathbf{4 3}$ & $\mathbf{4 4 , 8}$ & $\mathbf{5 3}$ & $\mathbf{5 5 , 2}$ \\
\hline
\end{tabular}

* Kanser dışında başka kronik hastalığı bulunan 96 hastanın toplam 144 hastalığı bulunmaktadır. Bu bireylerden 60 hastanın bir, 24 hastanın iki, 12 hastanın ise üç ayrı kronik hastalığı mevcuttur.

Tablo 6. Bitkisel ve hayvansal ürünler kullanan katıımcıların tercih ettiği ürünler.

\begin{tabular}{llc}
\hline & & Kullanan hasta sayısı \\
Ürünün adı & $\mathbf{n}$ & $\%$ \\
\hline Çörek otu & 32 & 41,0 \\
Isırgan otu & 17 & 21,8 \\
Zerdeçal & 13 & 16,7 \\
Yeşil Çay/lhlamur & 9 & 11,5 \\
Zencefil & 9 & 11,5 \\
Arı sütü/bal poleni & 8 & 10,3 \\
Kefir & 8 & 10,3 \\
Kekik & 8 & 10,3 \\
Resveratrol & 8 & 10,3 \\
Balık Yağı & 7 & 8,9 \\
Reishi Mantarı & 7 & 8,9 \\
Eşek sütü & 6 & 7,7 \\
Harnup pekmezi & 5 & 6,4 \\
Karabaşotu & 5 & 6,4 \\
Oğul Otu & 5 & 6,4 \\
Andız otu & 4 & 5,1 \\
Köpekbalığı kıkırdağı & 4 & 5,1 \\
Toplam & & \\
\hline & & $\mathbf{1 5 5}$ \\
\hline
\end{tabular}

*34 hasta bir, 21 hasta iki, 13 hasta üç, 10 hasta dört ürün kullanmaktadır.

\%50,0'ı (n=41) bilgisi bulunmadığını, \%11,0'ı $(n=9)$ ise genel hatları ile bilgi sahibi olduğunu belirtti.

\section{Tartışma}

Bölgeden bölgeye kullanılan ürünler farklılık göstermekle birlikte birçok TAT yöntemi tüm dünyada yaygın olarak kullanılmaktadır [7]. Yurdumuzdaki kanser hastalarında TAT kullanım oranları ise önceki bölümlerde aktarıldığı üzere dünya ortalamasının da üzerindedir (sırasıyla \%46,2 ve \%40). Bu nedenle ülkemizdeki hastalar arasında yüksek oranlarda TAT yöntemlerine başvurulmasının sebep ve sonuçlarının incelenmesi önem arz etmektedir. Çalışmamızda onkoloji hastalarının TAT kullanım eğilimleri ve sonuçlarına yönelik önemli veriler elde edilmiştir. Ancak araştırma Denizli il merkezinde faaliyet gösteren tek bir hastaneye başvuran kısıtlı sayıdaki hasta grubu ile gerçekleştirildiğinden sonuçlar il veya ülke çapındaki tüm hastaneler için genellenemez. Bu durum çalışmanın kısıtııığını oluşturmaktadır.

Araştırmamızda yaş ve cinsiyet gibi sosyodemografik özellikler ile TAT yöntemlerine başvurma sıklığı konusunda anlamlı bir fark bulunmazken şehir merkezlerinde ikamet eden 
hastaların köy ve kasabalarda yaşayan hastalara göre TAT yöntemlerini önemli oranda daha fazla yöneldikleri belirlenmiştir. Bu durumun şehir merkezlerinde yaşayan bireylerin tanı konma sürecinden sonra hastalığın nedenini şehir kirliliğine, stresine, ağırlıkla konvansiyonel tarım ürünleri ile besleniyor olmalarına ve çok daha az kimyasal gübre ve pestisit içeren, halk arasındaki tabiri ile "organik" tarım ürünlerine ulaşmalarının zor oldukları düşüncesine bağlayarak şifayı doğal ve zararsız olduklarını düşündükleri TAT yöntemlerinde arama istekleri ile ilişkili olabilir. Ülkemizde farklı zamanlarda değişik bölgelerde yapılan çeşitli çalışmalarda araştırmamızile sosyodemografik açıdan benzer sonuçlar elde edilmiştir [8, 14]. Üstündağ ve Zencirci'nin 2015 yılında Ankara ilinde yaptıkları çalışmada kadınlar arasında TAT kullanımının erkeklere göre önemli oranda fazla olduğu; meslek grupları açısından incelendiğinde ise ev hanımlarının en fazla TAT kullanım oranına sahip olduğu belirtilmiştir [2]. Çalışmamızda da ev hanımları TAT kullanımına en fazla yönelen grup olmuştur. Ülkemize ait verileri de kapsayan benzer bir diğer araştırmada da TAT yöntemlerine başvurma sıklığı kadınlar arasında erkeklere göre anlamlı derecede fazla bulunurken, çalışmamızda cinsiyetler açısından herhangi bir anlamlılık saptanmamıştır [7]. Yine aynı çalışmada TAT yöntemlerine köylerde yaşayan hastalarda şehirlerde yaşayanlara göre çok daha fazla başvurulduğu bildirilmiştir. Ancak çalışmamızda daha önce değinildiği gibi bunun tersi bir sonuç elde edilmiştir. Bu durum TAT yöntemi kullanım alışkanlıklarının ülke bazında homojenlik göstermediğini, bölgesel olarak farklılıklar bulunduğuna işaret etmektedir.

Araştırmamızda lisansüstü eğitim almış katılımcıların ( $n=11)$ hiçbiri TAT yöntemleri kullanmadıklarını bildirmişlerdir. Bu bireyler ile diğer eğitim derecelerine sahip katılımcılar arasında istatistiksel olarak anlamlı derecede bir farklılık bulunmuş olmasına rağmen lisansüstü eğitimli birey grubundaki katılımcı sayısının azlığı nedeniyle TAT kullanımının doğrudan eğitim seviyesi ile ilişkilendirilmesi doğru bir yaklaşım olmayacaktır. Diğer taraftan en fazla TAT kullanım oranına sahip grubun üniversite mezunları olması da, TAT kullanımı ile eğitim seviyesi arasında herhangi bir ilişki olmadığını göstermektedir. TAT kullanımı ile eğitim seviyesi ilişkisi konusunda yurdumuzda ve
Avrupa'da gerçekleştirilen çeşitli çalışmalarda araştırmamız ile benzer sonuçlar elde edilmiştir $[7,15,16]$.

Çalışmamızda TAT yöntemlerine başvuran katılımcıların oranının \%31,5 olduğu belirlenmiştir. Bu sonuç, yukarıda değinildiği üzere yurdumuzda daha önce gerçekleştirilen çalışmalardan elde edilen ortalamaya $(\% 46,2)$ göre daha düşüktür. Ancak neredeyse her üç hastadan birinin tedavi sürecinde TAT yöntemlerine başvurmuş olması oldukça düşündürücüdür. TAT yöntemi kullanan hastaların büyük bir çoğunluğunun $(\% 95,1)$ bitkisel/hayvansal ürünler tercih ettiği görülmektedir. Araştırmamızda katıımcılar arasında en sık kullanılan ilk üç ürünün sırası ile çörek otu $(\% 41)$, ısırgan otu $(\% 21,8)$ ve zerdeçal $(\% 16,7)$ olduğu belirlenmiştir. Çalışmamızın ve yurdumuzda yapılan çeşitli çalışmaların sonuçlarına göre ısırgan otu, çörek otu, kekik, zerdeçal ve sarımsağın TAT yöntemi olarak en sık kullanılan bitkisel ürünler; arı poleni, eşek sütü ve balık yağının ise en çok tüketilen hayvansal ürünler olduğu ortaya çıkmaktadır. Elde edilen veriler, gerek yurt içinde gerekse yurt dışında yapılan çeşitli çalışmaların sonuçları ile uyumlu olarak bitkisel veya hayvansal kaynaklı ürünlerin tıbbi yarar beklentisinin büyüklüğünden ziyade, daha kolay ulaşılabilir (pazar, aktar, doğadan toplama, vb.) ve diğer yöntemlere göre daha ucuz olmaları nedeniyle sıklıkla kullanıldığını düşündürmektedir $[5,7,15,17]$.

Araştırmamızda TAT yöntemi olarak bitkisel ve/veya hayvansal ürünlere başvuran katıımcıların \%15,4'ünün ( $n=12)$ aynı zamanda zem zem suyu içmek, muska yazdırmak, kurşun döktürmek, hoca ve türbe ziyaretlerinde bulunmak gibi çeşitli dini ve kültürel ritüellere de yöneldikleri belirlendi. Ancak ilginç olarak hiçbir hastanın dini ve kültürel ritüelleri tek başına yeterli görmeyerek beraberinde çeşitli bitkisel ya da hayvansal ürünlere de başvurdukları belirlenmiştir. Araştırmamızda hastalar diğer TAT yöntemlerini genelde "kurtarıcı çare" olarak benimserlerken; dini ve kültürel ritüellere ise daha çok "belki de bir faydası olur" düşüncesi ile başvurduklarını ifade etmişlerdir. Ülkemizde ve yurtdışında gerçekleştirilen pek çok araştırmada hastalarca dini ve kültürel ritüellere sıklıkla başvurulduğu ancak bu yöntemlerin genellikle çalışmamız ile benzer şekilde tek başlarına 
değil diğer herhangi bir TAT yöntemi ile birlikte kullanıldığı belirtilmiştir [2, 5, 7, 15, 18,19, 2022].

Araştırmamızda TAT yöntemlerine başvuran 82 hastadan \%92,7'sinin ( $n=76)$ bu yöntemleri asıl kullanım nedeninin tümörü yok etmek olduğu belirlenmiştir. Diğer taraftan katılımcıların \%7,3'ü $(n=6)$ bu yöntemleri sadece kemoterapinin yan etkilerini azaltmak amacıyla kullandıklarını belirtmiştir. Bu sonuç TAT yöntemlerine başvuran hastaların çoğunun bu yöntemleri "kanserden kurtarıcı bir çare" olarak görmekle birlikte bir kısım hastanın ise bu yöntemleri kullanmakla birlikte bu ürünlerden fazla bir beklentisi olmadığını da göstermektedir. Araştırmamıza katılan hastaların önemli bir bölümü TAT yöntemlerini hastalığın kendisinden kurtulmak için kullanırken; yurt içi ve yurt dışında yapılan çeşitli çalışmalarda kullanım amaçları sorulan hastaların büyük bir kısmı "kansere karşı herşeyi yapmış olmak", hastalığın etkilerini azaltmak ve duygusal iyileşme sağlamak gibi nedenlere kullandıklarını bildirmişlerdir [7, 15, 18, 21, 22]. Bu durum, kanser hastalarının TAT yöntemi kullanım amaçlarının zamanla veya yöre kültürüne özgü şekilde değişebildiğini göstermektedir.

Hastaların TAT yöntemi kullanım aralıkları (Tablo 3) incelendiğinde neredeyse yarısının $(\% 48,8)$ bu ürünleri her gün düzenli olarak kullandıkları görülmektedir. Diğer taraftan bu konuda asıl düşündürücü mesele ise çoğu zaman aynı bitkisel ürün için bile hastaların farklı zamanlarda kullanım yoluna gittiklerinin belirlenmiş olmasıdır. Örneğin, TAT yöntemi olarak ısırgan otunu tercih eden meme kanserli bir hasta söz konusu ürünü her gün düzenli olarak kullanırken, aynı teşhise sahip bir başka hastanın yalnız kemoterapiyi izleyen günlerde, bir diğerinin ise yalnız kemoterapi aldığı günler bu ürünleri kullandığı görülmektedir. Katılımcıların verdikleri yanıtlardan TAT ürünlerini kullanım yolu ve zamanı konusunda bilgi kaynaklarının çoğunlukla ilgili ürünü tedarik eden/satışını yapan kişi olduğu saptanmıştır. Araştırmamızda aynı aktardan satın alındığı iddia edilen aynı ürünlerin aynı teşhisli hastalara farklı şekillerde ve zaman aralıklarında kullanımının tarif edildiği belirlenmiştir. Yalnızca bu durum bile kanser tedavisinde TAT yöntemleri kullanmanın ne denli güvenilmez olduğuna işaret etmektedir. Diğer taraftan şaşırtıcı şekilde "Kullanım sonucunda şikayetlerinizde değişiklik oldu mu?" sorusuna hastaların \%15,9'u (n=13) "hiçbir faydası olmadı" şeklinde cevap verirken TAT yöntemi kullanan diğer tüm katılımcılar bu ürünlerden az ya da çok fayda gördüklerini belirtmişlerdir. Karmaşık ve henüz tam olarak aydınlatılmamış çeşitli farmakolojik etkilere sahip bu bileşiklerin şans eseri gerçekten faydalı gelmiş olma intimali göz ardı edilmemekle birlikte; bahsedilen faydaların bu ürünleri büyük bir beklenti ile kullanan hastalarda meydana gelen plasebo etki sonucu görülmesi büyük bir olasılıktır.

Hastaların TAT yöntemlerine başvurma konusunda en büyük tavsiye kaynağının tanıdık, komşu ve akrabaları olduğu, daha sonra medya ve internette yer alan reklam ve programlarından etkilendikleri belirlenmiştir. İşin ilginç ve üzücü yanı TAT yöntemi kullanan katılımcıların \%24,4'ünün ( $n=20)$ TAT yöntemi kullanımına hekim, eczacı ve hemşire gibi sağlık profesyonellerinin tavsiyesi ile başlamış olduklarını belirtmeleridir. Bu tür tavsiyelerde bulunan sağlık çalışanlarının bazılarının katıımcıların aile yakını olduğu, bazılarının ise eczane veya kendi özel muayenehanelerinde çalışan kimseler olduğu bildirilmiştir. Bu tedirgin edici durum çeşitli sağlık mesleği mensuplarının bile bilgisizce veya ticari kaygılar nedeniyle etki ve güvenliğinden emin olunmayan bu ürünlerin tanıtım ve pazarlamasını yaptığını ortaya koymaktadır.

Çalışmamızda, tanı konulması üzerinden geçen zaman arttıkça TAT yöntemlerine başvurma sıklığının da artış gösterdiği belirlenmiştir. Özellikle tedavi başlangıcının ilk altı ayından sonra hastalar arasında TAT kullanım oranlarının oldukça arttığı belirlenmiştir. $\mathrm{Bu}$ durum tanı konulmasının ardından hastaların büyük bir çoğunluğunun şifayı öncelikle medikal tedaviden umduğunu ancak zamanla karamsarlığa veya ölüm korkusuna yenik düşerek ilave çareler aradığına işaret etmektedir. Diğer taraftan araştırmamızda TAT yöntemlerine en çok başvuran hasta gruplarının sırası ile prostat, beyin ve mide tümörlü hastalar olduğu belirlenmiştir. 2014 yılında ülkemizde gerçekleştirilen bir tek merkezli çalışmada sıralama akciğer, meme ve jinekolojik kanserler şeklinde olurken; 2015 yılında yine ülkemizde gerçekleştirilen bir başka tek merkezli çalışmada ise sıralama mide/özefagus, meme ve kolorektal kanserler şeklinde olmuştur [2, 15]. Ülkemizi 
de kapsayan 14 Avrupa ülkesinden sonuçların derlendiği bir başka araştırmanın sonuçlarına göre ise sıralama pankreas, karaciğer ve kemik/ omurilik tümörleri şeklinde gerçekleşmiştir [7]. Bu durum, hastaların TAT yöntemlerine başvurma sıklığının belirli kanser türlerine özgü bir durum olmadığını, sonuçların zamana ve yöreye göre farklılıklar gösterebileceğine işaret etmektedir.

Hastaların kanser hastalığı haricindeki komorbiditelerin tedavilerinde kullanılan ilaçların kanser kemoterapisine etkileri, tedavinin gidişatını etkileyebilecek ve hayati sonuçları olabilecek bir konudur [23]. Bu konuda yurtdışı kaynaklı pek çok çalışma bulunurken ülkemizde ise çalışma sayısı yok denecek kadar azdır. Ülkemizde yapılan bir çalışmada 65 yaş ve üzeri kanser hastalarında komorbidite insidansının yüksek olduğu ve en sık görülen komorbiditenin ise kardiyovasküler sistem rahatsızlıkları olduğu bildirilmiştir [24]. Yurtdışında yapılan çalışmalarda komorbiditelerin sebebinin büyük oranda kanser oluşumuna da neden olan mesleki hastalıklar ve tütün ürünleri tüketimi gibi sebeplerden kaynaklandığı belirtilmektedir. Bu etkenlerin tüm organ ve dokuları etkileyerek kanser haricinde başta kardiyovasküler ve pulmoner sistem hastalıkları olmak üzere çeşitli rahatsızlıklara neden oldukları bildirilmiştir [12, 13]. Çalışmamızda kardiyovasküler hastalıkların eşlik eden hastalıklar arasında birinci sırada olduğu göz önüne alındığında sonuçların ülkemizde ve yurtdışında yapılan araştırmalar ile uyumlu olduğu görülmektedir.

Araştırmamızda TAT yöntemleri kullanan katılımcılardan on dokuz hastada düşük veya orta düzeylerde, bir hastada ise yüksek derecede etkileşim riski olduğu saptanmıştır. Kalp ritim bozukluğu için verapamil kullanmakta olan ve kanser kemoterapi protokolünde bulunan ilaçlar arasında kardiyotoksik yan etkileri olan doksorubisin isimli ilaç bulunan bir hastanın aynı zamanda hekiminin bilgisi dışında her gün yemek ve çay şeklinde ısırgan otu (Urtica dioica) tükettiği belirlenmiştir. Isırgan otu, sık kullanıldığında yapısında bulunan yüksek miktarda kalsiyum, potasyum ve urtisin isimli glikozid nedeniyle kalp üzerinde toksik etkilere yol açabilmektedir [25]. Tıbbi gereklilik nedeniyle belirtilen iki ilacı kullanırken, ilaveten uzun süre ve yüksek miktarlarda ısırgan otu kullanımının hayatı tehdit edici sonuçlar doğurması olasıdır. Diğer taraftan bitkisel ürünler kaynaklı potansiyel ilaç etkileşimlerinin henüz çok küçük bir kısmının aydınlatılmış olması nedeniyle çalışmada belirlenen etkileşim riskleri, gerçekte olan etkileşimlerin tamamını yansıtmamaktadır.

Çalışmamızda ilginç olarak komorbiditeli hastalar arasında diğerlerine göre önemli oranda $(p<0,05)$ yüksek seviyelerde TAT yöntemi kullanımı olduğu belirlenmiştir. Kanser kemoterapisi amacıyla genellikle iki ya da daha fazla ilaç bir kombinasyon halinde kullanılmaktadır [26]. Komorbiditeye sahip hastaların yaklaşık beşte birinin bu hastalıklar için üç ya da daha fazla ilaç kullandığı ve bunlara kemoterapi ilaçlarının da eklendiği düşünüldüğünde polimedikasyon ve polifarmasi gibi riskler de göz önüne alınmalıdır. Bu tür hastaların farmakolojik etkileri önceki bölümlerde açıklanan nedenlerle tam olarak kestirilemeyen çeşitli TAT yöntemlerini kullanması hayatı tehdit edici sonuçlar doğurabilir. Polimedikasyonun söz konusu olduğu hastalarda ilaç-ilaç, ilaç-TAT yöntemi, ilaç-besin etkileşimleri konusu tam bir muammaya dönüşmektedir. Kemoterapi alacak komorbiditeli hastalarda tedavi başlangıcında TAT yöntemleri kullanımından kaçınılması, polifarmasi intimaline karşı kullanılan ilaçların ve klinik tablonun yeniden ele alınarak ilaç seçimi ve doz ayarlaması yapılması, ayrıca ilaç kullanım zamanlarının yeniden değerlendirilmesi diğer hastalara göre daha çok önem arz etmektedir.

Sonuç olarak, araştırmamızda yurdumuzun çeşitli bölgelerinde geçmiş yıllarda yapılan çalışmalara göre TAT kullanım oranlarının bir miktar daha düşük çıktığı, ancak hala yüksek bir seviyede olduğu belirlenmiştir. TAT ürünlerinin antineoplastik ajanların etkilerini azaltma veya toksik etkilere neden olma potansiyelinden dolayı, hastalar tedavinin başında konu hakkında çok iyi bilgilendirilmelidir. Çalışmamız hastaların bu konuda daha çok eğitime intiyacı olduğunu ortaya koymaktadır. Tedavi sürecinde hastanın TAT yöntemi kullanma isteği, olası sonuçları iyice anlatılmadan doğrudan reddedilmemelidir. $\mathrm{Bu}$ durumun hastaların TAT kullanımını sağlık personelinden gizli olarak sürdürmelerine yol açabileceği unutulmamalıdır.

Çıkar ilişkisi: Yazar çıkar ilişkisi olmadığını beyan eder. 


\section{Kaynaklar}

1. Bao $\mathrm{Y}$, Kong $\mathrm{X}$, Yang $\mathrm{L}$, et al. Complementary and alternative medicine for cancer pain: an overview of systematic reviews. Evid Based Complement Alternat Med 2014;2014:170396. https://doi. org/10.1155/2014/170396

2. Üstündağ $S$, Demir Zencirci $A$. Complementary and alternative medicine use among cancer patients and determination of affecting factors: a questionnaire study. Holist Nurs Pract 2015;29:357-369. https://doi. org/10.1097/HNP.0000000000000113

3. White JD. Complementary and alternative medicine research: a National Cancer Institute perspective. Semin Oncol 2002;29:546-551. https://doi.org/10.1053/ sonc. 2002.50003

4. Bardia A, Barton DL, Prokop LJ, Bauer BA, Moynihan TJ. Efficacy of complementary and alternative medicine therapies in relieving cancer pain: a systematic review. J Clin Oncol 2006;24:5457-5464. https://doi. org/10.1200/JCO.2006.08.3725

5. Smith PJ, Clavarino A, Long J, Steadman KJ. Why do some cancer patients receiving chemotherapy choose to take complementary and alternative medicines and what are the risks? Asia Pac J Clin Oncol 2014;10:110. https://doi.org/10.1111/ajco.12115

6. Deng G, Cassileth B. Complementary or alternative medicine in cancer care-myths and realities. Nat Rev Clin Oncol 2013;10:656-664. https://doi.org/10.1038/ nrclinonc.2013.125

7. Molassiotis A, Fernadez-Ortega P, Pud D, et al. Use of complementary and alternative medicine in cancer patients: a European survey. Ann Oncol 2005;16:655663. https://doi.org/10.1093/annonc/mdi110

8. Kav S, Hanoğlu Z, Algier L. Türkiye'de kanserli hastalarda tamamlayıcı ve alternatif tedavi yöntemlerinin kullanımı: literatür taraması. UHOD 2008;18:32-38.

9. Özçelik H, Fadıloğlu Ç. Kanser hastalarının tamamlayıcı ve alternatif tedavi kullanım nedenleri. Türk Onkoloji Dergisi 2009;24:48-52.

10. Nazik E, Nazik $H$, Api M, Kale A, Aksu M. Complementary and alternative medicine use by gynecologic oncology patients in Turkey. Asian Pac J Cancer Prev 2012;13;21-25. https://doi.org/10.7314/ apjcp.2012.13.1.021

11. Posadzki P, Watson L, Ernst E. Contamination and adulteration of herbal medicinal products (HMPs): an overview of systematic reviews. Eur J Clin Pharmacol 2013;69:295-307. https://doi.org/10.1007/s00228-012$1353-z$

12. Williams GR, Deal AM, Lund JL, et al. Patient-reported comorbidity and survival in older adults with cancer. Oncologist 2018;23:433-439. https://doi.org/10.1634/ theoncologist.2017-0404
13. Dutkowska AE, Antczak A. Comorbidities in lung cancer. Pneumonol Alergol Pol 2016;84:186-192. https://doi.org/10.5603/PiAP.2016.0022

14. Uğurluer G, Karahan A, Edirne T, Avni H. Ayaktan kemoterapi ünitesinde tedavi alan hastaların tamamlayıcı ve alternatif tıp uygulamalarına başvurma sıklığı ve nedenleri. Van Tıp Dergisi 2007;14:68-73.

15. Taş F, Üstüner Z, Can G, et al. The prevalence and determinants of the use of complementary and alternative medicine in adult Turkish cancer patients. Acta Oncol 2005;44:161-167. https://doi. org/10.1080/02841860510007549

16. Işıkhan V, Kömürcü Ş, Özet $A$. et al. The status of alternative treatment in cancer patients in Turkey. Cancer Nurs 2005;28:355-362.

17. Yavuz M, İlçe AÖ, Kaymakçı Ş, Bildik G, Dıramalı A. Meme kanserli hastaların tamamlayıcı ve alternatif tedavi yöntemlerini kullanma durumlarının incelenmesi. Türkiye Klinikleri J Med Sci 2007;27:680-686.

18. Algier LA, Hanoglu Z, Ozden G, Kara F. The use of complementary and alternative (non-conventional) medicine in cancer patients in Turkey. Eur $\mathrm{J}$ Oncol Nurs 2005;9:138-146. https://doi.org/10.1016/j. ejon.2005.03.010

19. Kurt $H$, Keşkek ŞÖ, Çil $T$, Canatarlıoğlu A. Complementary/alternative therapies in patients with breast cancer. Türk Onkoloji Dergisi 2013;28:10-15. https://doi.org/10.5505/tjoncol.2013.827

20. Bahall M. Prevalence, patterns and perceived value of complementary and alternative medicine among cancer patients: a cross-sectional, descriptive study. BMC Complement Altern Med 2017;17:345. https://doi. org/10.1186/s12906-017-1853-6

21. Düzen KÖ, Korkmaz M. Kanser hastalarında semptom kontrolü ve tamamlayıcı ve alternatif tıp kullanımı. DEUHFED 2015;8:67-76.

22. Öztürk R, Şatır DG, Sevil Ü. Jinekolojik kanserli hastaların tamamlayıcı ve alternatif tedavi kullanım durumları ve tutumlarının incelenmesi. Gaziantep Medical Journal 2016;22:141-147. https://doi. org/10.5152/EurJTher.2016.006

23. Gehrke AK, Feuerstein M. Cancer, comorbidity and workplace discrimination: the US experience. Eur J Cancer Care 2017;26. https://doi.org/10.1111/ ecc. 12748

24. Tuna S. Kanserli geriatrik hastalarda komorbidite ve klinik değerlendirme. Türk Onkoloji Dergisi 2007;22:192-196.

25. Dar SA, Ganai FA, Yousuf AR, Balkhi MU, Bhat TM, Sharma P. Pharmacological and toxicological evaluation of Urtica dioica. Pharm Biol 2013;51:170180. https://doi.org/10.3109/13880209.2012.715172 
26. Lu DY, Chen EH, Wu HY, Lu TR, Xu B, Ding J. Anticancer drug combinations, how far we can go through? Anticancer Agents Med Chem 2017;17:2128.

Etik kurul izni tarih ve sayısı: Pamukkale Üniversitesi Girişimsel Olmayan Klinik Araştırmalar Etik Kurulu 17/07/2019-E.13570 